\title{
Sexual Harassment of Women at Workplace in Assam: The Present Scenario
}

Dr Polly Vauquline ${ }^{\dagger}$

\section{Abstract}

The United Nations General Assembly has delegated 25 November as the International Day for the Elimination of Violence Against Women (VAW). This issue of the journal Space and Culture, India is dedicated to raising further awareness against VAW, inequalities and discrimination. Now I turn to discuss the abstract of this editorial.

Greater access to public spaces, entry into the professional space and engagement in different sectors of labour forces are the diverse forms of opportunities urbanisation and modernisation is supposed to provide to each individual including women. However, one could argue that both urbanisation and modernisation have begeted gender discrimination. And the degree of discrimination is faced mostly by women putting them in a vulnerable position by generating women-centric workplace violence-mainly sexual harassment of women at workplace (SHWWP). This paper highlights the findings of two research studies: Workplace Safety and Dignity for Women in Assam and Prevention, Prohibition and Redressal of Sexual Harassment at Professional Places in Assam: Post 23rd April 2013 carried out by the author during the period 2017-2019.

According to the National Crime Records Bureau (NCRB), 2017, the state of Assam contributes 6.4 percentage points of state-share to all-India share of crime against women; its overall crime rate against women when calculated as a crime per one-hundred thousand of the population stands at 143.6. Evidently, the state of Assam also has high occurrences of SHWWP, which stands at $44 \%$ but only $2.7 \%$ complaint cases were lodged. The findings also uncovered that there exist weak and inadequate complaint mechanisms in the state even after the existence of Sexual Harassment of Women at Workplace (Prevention, Prohibition and Redressal) Act, 2013.

Keywords: Sexual Harassment; Workplace; Women; Complaint Mechanism; Assam

\footnotetext{
'Professor, Department of Women's Studies, Gauhati University, Email: pollyvauquline@gauhati.ac.in (C) 2019 Vauquline. This is an Open Access article distributed under the terms of the Creative Commons Attribution License (http://creativecommons.org/licenses/by/2.0), which permits unrestricted use, distribution, and reproduction in any medium, provided the original work is properly cited.
} 


\section{Introduction}

This issue is dedicated to the victims of violence against women. In this editorial, I discuss sexual harassment of women at workplace (SHWWP) To trace down the SHWWP one has to travel back to the European colonial period where women mostly worked as house-helps, and faced sexual harassment not just from their male employers but also from the other superior male house-helps. Due to the hierarchy of work these paid female house helps were regarded as the lowest and vulnerable of all (Cela, 2015). It can be understood that sexual harassment did not just originate with industrialisation when women came up to work in public sectors like industries, schools, and others, but have existed since the colonial period.

It remains well documented that for a very long time, workplace used to be a male's territory and women's noticeable venture into this masculine space happened much later compared to men thereby, interposing a space which was till then a male domain or bastion (Kihnley, 2000; see, also, Bhattacharyya Sarma, 2009). Greater access to public spaces, subsequent entry into the professional space and engaging themselves into different forms of work are the diverse forms of opportunities urbanisation and modernisation provides to women. This shift of women entering different sectors of work was a progressive step no doubt, but it has also brought out different perspectives of gender discrimination faced by women often pushing them into vulnerable positions generating some specific women-centric problems (Vauquline, 2007; Vauquline 2012). Men being the dominant population in the workplaces/organisation have given rise to different forms of male-on-female violence such as, sexual harassment, which is a threat mostly encountered by women in workplaces across the world; bearing an obvious effect on women's physical and mental state jeopardising the quality of the work and weakening gender equality in work-places or organisations (Institute of Social Development, 2014). International Labour Organization (ILO) states "workplace sexual harassment is a barrier towards its primary goal of promoting decent working conditions for all workers" (McCann, 2005: vii). This paper is based on the major findings of two research projects carried out by the author using mainly interviews and focus groups. The first study was a collaborative research project with North East Network, Guwahati, Assam and the Department of Women's Studies, Gauhati University where the author, Dr Polly Vauquline and Anurita Hazarika were the Principal Investigators. The second study was a UGC sponsored Major Research Project, where the author was the Principal Investigator and Dr Jyotisikha Dutta, the Coinvestigator. The following section discusses the effects of sexual harassment at workplace.

\section{Effects of Sexual Harassment of Women at Workplace}

The consequences of SHWWP are as varied and complex as the women who endure it (Morgan, 2001). The greater the power disparity, the more distressing the experience is likely to be (Benson \& Thomson, 1982; Bhattacharyya, 2018). Feelings of violation are particularly strong when women are harassed by authorities entrusted with their care. Sexual harassment is especially traumatic when employers, coaches, mentors, therapists, doctors, clergy or colleagues commit it (Rutter, 1989; Bhattacharyya, 2018). Even though no two sexual harassment experiences are alike, analysis of women's narratives about how sexual harassment feels and its effect on their lives has uncovered a few salient themes. For most, loss is a core experience. Coping with the negative effects of sexual harassment is emotionally distressing as well as physically exhausting (Stambaugh, 1997). Anyone subjected to sexual harassment can feel humiliated, demoralised, experience a loss of self-confidence and self-esteem and feel violated and stripped of dignity. The impact of sexual harassment can be severe, and have a debilitating effect on the personality, working life and social behaviour of the target of harassment (Murthy, 2004). So common, indeed, is this social malady that most women 
themselves fail to recognise it as a problem and treat it as 'normal'. Others over the years develop internal coping mechanisms to deal with the menace (Dasgupta, 2001).

Evidently, portraying a woman as an object of sexual exploitation can undermine her selfimage and confidence (Bhattacharyya, 2015; 2016). Over two decades ago, Sandy Welsh (1999) argued that the instances linked to harassment are more about gender than sexuality. It is therefore arguable that instance of sexual harassment of a particular individual signals that a particular wo(man) is uninvited and unacceptable in that particular workplace (Reskin and Padavic, 1994) where the individual experience a sense of (dis)belonging (Bhattacharyya, 2015; 2016). Hence, one can easily argue that sexual harassment is likely to exist wherever there is an existence of unequal distribution of power between men and women. It is unwanted and unwelcomed behaviour based on gender. It is part of the whole syndrome of discrimination and exploitation that upholds unequal economic and social structures thriving in an atmosphere of threat, terror and reprisal. Sexual harassment continues to hamper employment opportunities for many women (Dasgupta, 2001). The following section describes the SHWWP in the Indian context.

\section{Indian Scenario}

In India, SHWWP was not recognised as a public issue until the infamous incident of $\mathrm{N}$. Radhabai and her continued struggle to seek justice from 1973 to $1995^{1}$ (Vauquline and Hazarika, 2019).
Again, the widely known Bhanwari Devi case ${ }^{2}$ of 1992 revealed the presence of sexual harassment faced by millions of working women across the country, irrespective of their location of work. This case, after a long legal battle brought into force the Supreme Court of India's Vishakha Guidelines. In the case of Vishakha Vs. State of Rajasthan 1997, sexual harassment at workplace came up to be accepted as an encroachment of human rights and rules were instituted against it (Ministry of Women and Child Development, 2015).

Prior to the existence of the Vishakha Guidelines, women subjected to sexual harassment had to use the provisions of Section 354 and 509 under IPC (Indian Penal Code) for outranging the modesty of women. Even though the apex court of India made it mandatory for employers to follow the guidelines, many organisations failed to adhere to the guidelines. Some other loopholes came into observation that the Vishaka judgement was unclear on how the complaint mechanism would work for women working in unorganised or informal sectors (Institute of Social Development, 2014). Post the Vishakha Judgment, nearly after a one and a half-decade that is in 2013 the Parliament of India passed the Sexual Harassment of Women at Workplace (Prevention, Prohibition and Redressal) Act; the following section discusses the same.

protest against the marriage of a one-year old girl in Rajasthan. Her protest was met with resentment and some form of harassment from the men of that community. Subsequently, she went to the local authority to report but no action was taken at this act of a lower caste potter women as the harassers belonged to a higher community. On the contrary, these higher caste men gang-raped her, exhibiting the power of the high caste men. As the local authority did not take any action, a Public Litigation was filed by Vishaka and various women groups against the State of Rajasthan Vs Union of India before the Supreme Court of India. The apex court of India pronounced the breakthrough judgment in 1997, widely known as the Vishaka Judgement and framed legal guidelines under the Indian Constitution and CEDAW (Ministry of Women and Child Development, 2015). 
Sexual Harassment of Women at Workplace (Prevention, Prohibition and Redressal) Act, 2013

As discussed above, the plea for the amendment of the loopholes in the guidelines went on for sixteen years since the pronouncement of the Vishakha Judgment. It was later brought out by the Parliament of India as the act of Sexual Harassment of Women at Workplace (Prevention, Prohibition and Redressal) Act, 2013 (henceforth will be referred as SH Act). Upholding the spirit of the Vishakha Judgement, the new law relies on the definition of sexual harassment as given by the Supreme Court of India in 1997. This new legislation further attempts to provide protection to women working in both formal and informal sectors. While making the structural provision for and Internal Complaint Committee (ICC) in every workplace with more than ten workers and provision of a Local Complaint Committee (LCC) for all the women working in other places with less than ten workers (Ministry of Women and Child Development, 2015). The SH Act as mentions provides emphasis on the elements of "Prevention, Prohibition and Redressal" sexual harassment of women from workplaces and has laid down few parameters in the Act. For the purpose of Prevention and Prohibition of sexual harassment of women its states the establishment of ICC and LCC as mentioned above, with the guidelines of having a senior female preceding officer; who would be in authority for three years, with two outside members - one with a legal background and the other from an NGO working with women's issues. The workplace should also organise sexual harassment workshops or awareness campaigns or training involving both the male and female employees. Besides, the Act states that the sexual harassment is to be mentioned as

\footnotetext{
${ }^{3}$ At the time of passing of the Sexual Harassment of Women at Workplace (Prevention, Prohibition and Redressal) Act, 2013, homosexuality in India was considered a criminal activity. It was only on 6 September 2018 that the honourable Apex Court of India decriminalised homosexuality through the Johar Judgement (Kakoti Borah, 2018)
}

misconduct in their company service rules. In addition, the Act also requires employers to ensure dissemination of information and awareness regarding their policy for prohibiting sexual harassment in the workplace, capacity building and skill development of the ICC members, creating dialogue and publicising the names and contact information of the committee members to prevent any form of sexual harassment in the workplace (Ministry of Women and Child Development, 2015).

It is a fact that SH Act lacks gender neutrality as it does not include men, homosexual ${ }^{3}$ or transgender individuals who may also be victims of SHWWP (Raghuwanchi, 2017; Pradeep \& Ray, 2017) but addresses only to the grievances of women. At the same time, it is reported ${ }^{4}$ that sexual harassment is more prevalent against women and young women, separated, widowed or divorced women, women employed in "nontraditional" or male-dominated professions, women working in informal sectors of the economy and migrant workers are more vulnerable. Alongside the scarcity of data (Ramanathan et al., 2005) and the few studies (Centre for Transforming India, New Delhi, 2010) carried out on SHWWP indicates that there is a constant and gradual rise of such incidences even after the existence of the SH Act. It is also reported that as many as $70 \%$ of the women do not report sexual harassment at the workplace for varied reasons (Bhattacharyya, 2018; Chachra, 2017).

The recent worldwide outrage against $\mathrm{SH}$ roused by the \#MeToo movement ${ }^{5}$ and others have exposed the insidious and complex nature of SHWWP. Women for a very long time have been silent about SHWWP (Bhattacharyya, 2018) and still continue to be. The \#MeToo movement is praiseworthy for breaking the long-held silence of sexual harassment that women face at

\footnotetext{
${ }^{4}$ McCann, Deirdre, Sexual harassment at work: National and international responses, International Labour Organisation, 2005. Retrieved on 30 August 2019 from, http://www.ilo.org/public/english/protection/condtrav/p df/2cws.pdf

${ }^{5}$ This movement was launched initially by Tarana Burke in 2006 to raise awareness and help victims of sexual assaults (Bhattacharyya, 2018).
} 
workplace. The next section discusses SHWWP in Assam.

\section{SHWWP in Assam}

Many questions arise regarding the safety and the sense of free and secure space for women in their professional space. The gendered scenario raises the spectre of women's vulnerability (Gupta and Hazra, 2007). If so, then what is the scenario of SHWWP in Assam? It is saddening to witness that Assam ranks a higher position in the country in reported crime against women (NCRB, 2017). It is to be noted here that most of the urban hubs of the entire North East India are located in Assam, as it the gateway to North-East India. The central question that arises here is whether women of Assam are vulnerable to sexual harassment at workplace, in the same way, like other forms of reported crime against women? If so, do the women of Assam have access to address their grievances of sexual harassment at the workplace? Do women report cases of SHWWP in Assam? Is the Act implemented in reality? Focusing on these questions, two intensive research studies were carried out in 12 urban centres (Guwahati, Barpeta, Kokrajhar, Tezpur, Dibrugarh, Diphu Silchar, Nagaon, Sibsagar, Jorhat, Kajalgoan and Dhubri) of Assam during the period 2016-2018 where 553 respondents were interviewed across the state. The study attempted to cover a wide range of categories of workplaces and organisations, including offices under the central, state and semi governments, educational institutes, private organisations like the media channels, newspapers, non-profit organisations, financial institutes and others (see, Table 1).

\begin{tabular}{|l|l|l|l|}
\hline $\begin{array}{l}\text { Organisation } \\
\text { Interviewed }\end{array}$ & $\begin{array}{l}\text { Proportion in } \\
\text { (percentage) }\end{array}$ & $\begin{array}{l}\text { Organisation } \\
\text { Interviewed }\end{array}$ & $\begin{array}{l}\text { Proportion in } \\
\text { (percentage) }\end{array}$ \\
\hline Central Government & $\mathbf{8 . 6 \%}$ & NGOs & $\mathbf{1 . 4 \%}$ \\
\hline State Government & $\mathbf{2 3 . 8 \%}$ & $\begin{array}{l}\text { Small Individual } \\
\text { Business }\end{array}$ & $\mathbf{1 . 4 \%}$ \\
\hline Semi Government & $\mathbf{6 . 1 \%}$ & $\begin{array}{l}\text { Unorganised Sector } \\
\text { Public Sector }\end{array}$ & $\mathbf{5 . 2 \%}$ \\
\hline Undertaking & $5.5 \%$ & $\begin{array}{l}\text { Individual Owned } \\
\text { Enterprise }\end{array}$ & $\mathbf{5 . 2 \%}$ \\
\hline Private Sector & $32.9 \%$ & Others & $3.3 \%$ \\
\hline Source: Workplace Safety and Dignity for Women in Assam & \\
\hline
\end{tabular}

Primary data were collected from the field using semi-structured interview schedules designed separately for employees and employers. A separate interview guide was used for FGD's (Focus Group Discussion's). Five FGD's were conducted in Guwahati and one in each of these urban centres; Jorhat, Tezpur, Barpeta, Silchar, Nagaon, Sibasagar and Kajalgaon comprising of five respondents selected after the interviews. However, due to the non-availability of information about unorganised sector workplaces, households where women worked as maids, brick kilns, and similar organisations were studied under this category. Both the studies were undertaken to understand the different perspectives about SHWWP. Some significant but disturbing findings of these two studies are illustrated below.

\section{Understanding about SHWWP:}

To have a realistic assessment of the existence of SHWWP, it was essential to explore the respondents' perspectives about SHWWP. In both these studies, the respondents did reveal that they had adequate understanding about SHWWP, which accounted to more than $60 \%$; however, $18 \%$ expressed their ignorance about the issue, and $21 \%$ offered no comments on it. The majority, who said that they knew SHWWP, were not clear what could constitute the same. In one of the study, the respondents acknowledged that it was difficult for them to distinguish between harassment in general and 
harassment which had sexual connotations. And on the other study when it was explored indepth, it emerged that the severe forms of $\mathrm{SH}$ such as rape, molestation, physical contacts or those physical moves which makes them sexually intimidated were considered by majority of the respondents as $\mathrm{SH}$. Around 50\% of the employees were ignorant that verbal sexist abuses and hostile work environment too were included as SHWWP. The awareness of the $\mathrm{SH}$ Act and occurrences, forms and patterns of sexual harassment at workplace are discussed in the following sub-sections.

\section{Awareness of the SH Act}

There are differences in the proportion of knowledge about SH Act among the employees and employers. While $51.8 \%$ of the employers expressed that they were aware of the Act; amongst the employees, the awareness of this Act stood at $38.1 \%$. . The study also revealed that most of the employees came to know of the Act through their own efforts to learn about their rights. Of the $38.2 \%$ of the employees who were aware of the Act, only one-third learnt about it from the policies at their respective workplaces, while the remaining gained this knowledge through newspapers, colleagues, the internet or television. In addition to the above mentioned sources, the employers procured information about the SH Act through the pieces of training they have attended and by being a part of the grievance cells. Less than $10 \%$ of the respondents had a thorough understanding of the Act and a handful of them have actually read the SH Act.

\section{Occurrence of SHWWP}

When the responses regarding the occurrence of SHWWP are compared between the two studies, variations are observed. These disparities were also observed with the variation of the method applied to collect the data. In the first report (Vauquline \& Hazarika, 2019) when the participants were directly interviewed, very few employees, $1.41 \%$, revealed that they were victims of $\mathrm{SH}$. Whereas, in the second report (Vauquline \& Dutta, 2019), $19 \%$ of the employees expressed that they faced some forms of $\mathrm{SH}$ at their workplace, a larger proportion of $73.5 \%$ employees stated that they did not face any form of $\mathrm{SH}$ at their workplace and only $7.4 \%$ of women were not comfortable to respond to this question.

However, in the Focus Group Discussions (FGDs), $41 \%$ of the employees admitted to encountering some forms of sexual harassment at their workplace. The remaining $59 \%$ of the respondents of the FGDs said that they did not encounter direct acts of sexual harassment, but shared incidents of certain unwelcome or unwanted behaviours from the male colleagues, which were accepted as normal by them. They shared experiencing acts such as, comments on personal lives, jokes, abuses and staring which according to them did not amount to SHWWP. For $2.6 \%$ of the women it was a daily affair. The same proportion of women, $2.6 \%$, reported being frequently sexually harassed and out of which $9 \%$ faced it occasionally.

\section{Forms of SHWWP Faced by Employees}

As mentioned above, only $1.41 \%$ of the employees disclosed that they were victims of $\mathrm{SH}$ at the workplace when they were directly interviewed. It provided a completely different picture in the FGDs conducted amongst the employees.

There were $44.2 \%$ employees who expressed that they experienced unwanted physical contact and advances at the workplace (Figure 1). Mental harassment, which was connected to a hostile work environment or different forms of explicit sexual overtures, was reported by $21.5 \%$, while $29 \%$ faced verbal harassment such as sexually coloured remarks and $5.3 \%$ reported other forms of harassment.

This change in their responses regarding their experience of $\mathrm{SH}$ at the workplace can be ascribed to the method applied to probe the issue. In the beginning of the discussion, the respondents were hesitant to express. Gradually after some form of confidence and bonding were built up with the interviewer and the other members of the group they poured out their suppressed experiences of $\mathrm{SH}$. 


\section{Forms of SHWWP faced by employees}

- Verbal $\square$ Physical Mental $\square$ Other

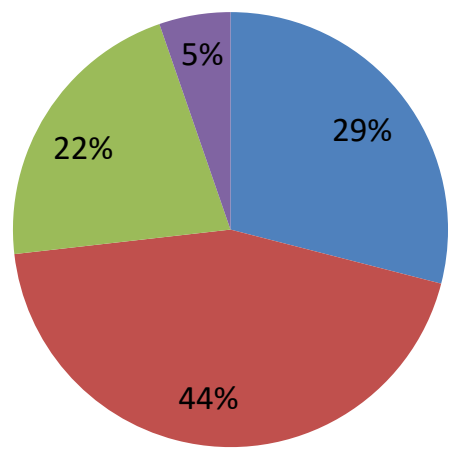

Figure 1: Forms of SHWWP faced by employees

Source: Workplace Safety and Dignity for Women in Assam

\section{Pattern of Occurrence of SHWWP}

SHWWP is of different forms. They are sexual in context and can be physical, mental as well as physiological It was intended to understand the pattern of occurrence of $\mathrm{SH}$ in their workplace by exploring if the employees encounter the same form of $\mathrm{SH}$ or it differed according to situations. When probed, it revealed that the pattern of occurrences varied. Majority of the women faced different forms of $\mathrm{SH}$ at different times in their workplace, it accounted for $6.3 \%$. However, $2.6 \%$ of women faced the same form (meaning) of $\mathrm{SH}$ in their workplace. Again there were $4.8 \%$ of women who could not provide a distinctive answer to this query as its occurrences did not have any specific pattern.

In those occasions, when the harasser was the same person, the forms of SH also tended to be same. When the workplace environments were hostile in nature than the forms of $\mathrm{SH}$ also tend to differ. Again, when the harasser subsequently makes more advances, the forms of $\mathrm{SH}$ also gradually changes. It happens more when the woman is silent about the incidences and do not make any move to complain. The various situations through which employees face $\mathrm{SH}$ are discussed below.
Situations in which Employees' Face SH

In the FGDs, the employees narrated the situations in which they or their colleagues have faced $\mathrm{SH}$. There were instances where an employee's senior used to call the woman to his chamber and show offensive videos. It used to happen in the evening or when everybody/other employees used to be busy with their work. She was junior to him.

There were also incidences of $\mathrm{SH}$ when the employees were away from their workplace on official duties. In such situations, they had to travel and work away from their workplace to meet clients for business purposes. On some such situations the employees' felt uncomfortable (did not specify the types of discomforts) and felt that the intentions of the clients with whom they were working were not noble or decent. One such respondent worked for an insurance company.

Incidences of $\mathrm{SH}$ has also emerged, where the women were sexually harassed in other workplace-related spaces. It was on their way back to their hostel at night. 


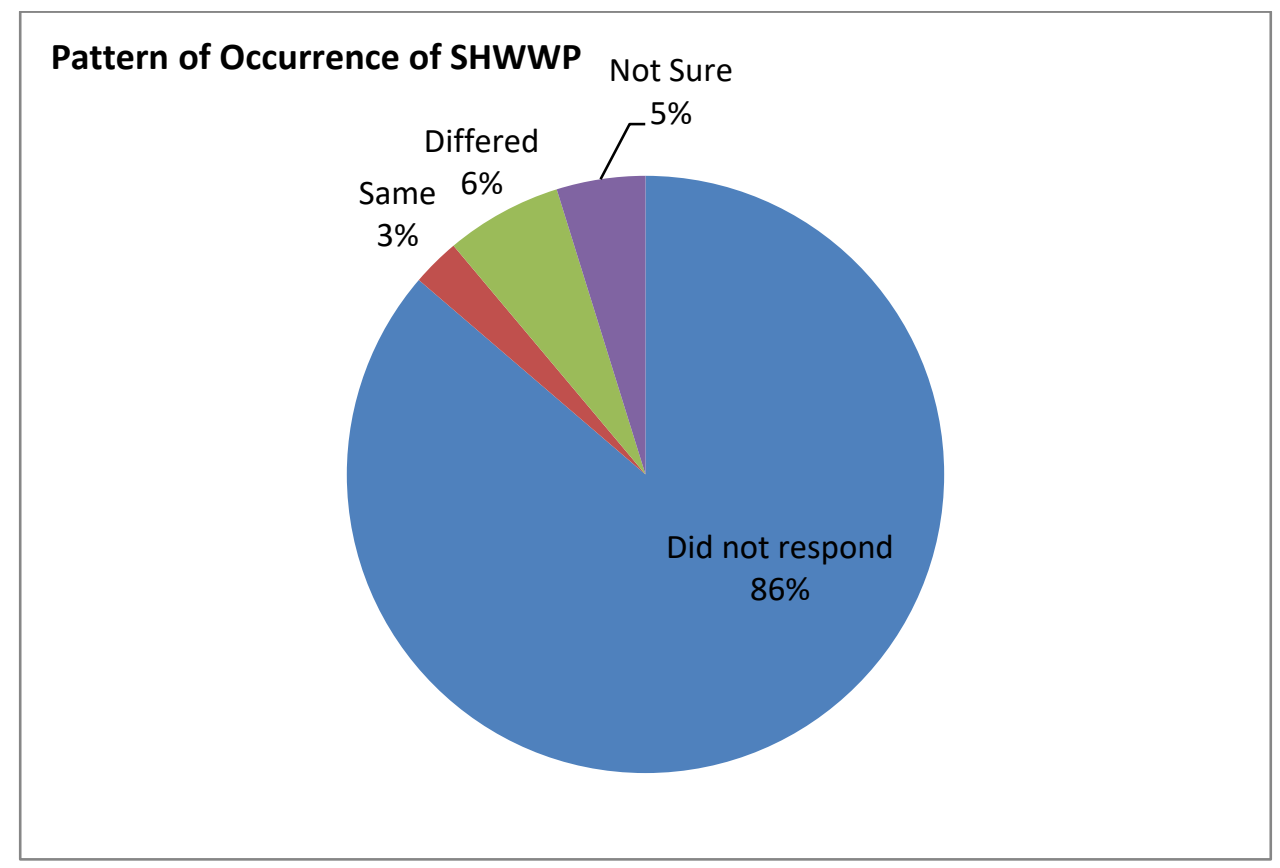

Figure 2: Pattern of Occurrence of SHWWP

Source: Prevention, Prohibition and Redressal of Sexual Harassment at Professional Places in Assam: Post 23rd April, 2013

$\mathrm{SH}$ occurred during different periods of their duty hours. Some of the employees stated that it was more when there are lesser people in the workplace or when the employee was alone. It happens during those periods of the working hours when the workplaces become vacant with nobody around, during lunch hours or when the workplace is about to close. There were instances of SH of the employees by their senior male officers when they had to travel with them for office works.

For those women who work in educational institutions, instances of sexual harassment were reported when they had to evaluate examination papers in isolated rooms. These happened more when they were required to go to some other institution for such tasks. They also faced SH when they worked till late hours in their workplaces.

Nurses and female hospital staffs felt unsafe during their night duties both in the workplace as well as in the public places. During night duties, they usually avoided those places of the workplace which they consider as 'risky' to venture during night hours. These also illustrate that all the spaces of their workplace are not safe for them during night hours and that the safety of the workplace changes according to time too.

Women in higher positions or holding some form of the higher and respectable portfolio were also at times targeted and became victims of SHWWP. A female employee who was a member of the governing body of her institution stated, 'Since I am a governing body member I faced more sexual harassment than the other female employee.'

There are also women who were reluctant to reveal incidences of $\mathrm{SH}$ at workplace stating that they 'can't reveal'. One of them stated that, 'Sorry I cannot reveal the incident as it is confidential.'

\section{Status of the Complaint Mechanism in Assam}

The SH Act clearly mentions in Chapter 2, 4. (1) of the Act that it is the responsibility of each employer to constitute the Internal Complain Committee (IC) in their workplace not only to redress but also to prevent and prohibit SHWWP. The Act has designed different mechanism to redress, prevent as well as prohibit such derogatory act of $\mathrm{SH}$. Putting these mandates into practice are considered as duties and responsibilities of any workplace. The study 
reveals a deplorable state of the complaint mechanism in the workplaces of Assam.

\section{Existence of Complaint Mechanism}

In one of the studies by Vauquline and Hazarika, (2019), it was found that majority of the employers and employees were not knowledgeable about the existence of any form of complaints mechanism in their workplace. It was found that $68.9 \%$ of the offices do not have a complaints mechanism to address SHWWP. In the other study (Vauquline and Dutta, 2019), when the employees were specifically enquired about the existence of Internal Complaint Committee (thereafter will be referred to as IC) their responses signal an alarming state of condition of the complaint mechanism in Assam.

It clearly illustrates that only $31 \%$ of the employees were aware of the existence of ICS (Figure 3). However, when more questions were asked regarding the ICs of their respective workplaces the followings facts emerged. Of the $31 \%$ who responded that they have ICs in their workplace, only $8.5 \%$ of the employees mentioned that it is named as Internal Complaints Committee; $5 \%$ of the respondents did not remember the name of their complaint mechanism and $1 \%$ stated that they were not aware of the name of the complaint mechanism provided by their institution. Not being aware of it also indicates inadequate implementation of the Act because in the Act it is mentioned that the IC will be formed 'by an order in writing' (Chapter II, 4.1). In few of the workplaces (1\%) the aggrieved women complain directly to the Human Resource (HR) management. In such cases, the workplace also did not find it necessary to have a separate committee to address issues pertaining only to SHWWP. This finding emerged while interviewing employers.

It also means that in the absence of a complaints mechanism, there is no space for aggrieved women to complain and seek redress at their workplace in situations of SHWWP. On the other hand, the employers also do not get to know if there is occurrence of SHWWP or take required action.

\section{Types of Complaint Mechanisms Other Than ICs}

Even though the Act clearly mentions that it should be termed as 'Internal Complaints Committee' and will be known as IC, however in practise the complaint mechanisms were termed by wide-ranging names in different workplaces. They were known as women's cell, district women cell, anti-sexual harassment cell, grievance cell, teachers' unit or women's forum, mahila ayog committee, social workgroup, among others. Interestingly, some workplaces did not have a formal structured complaints mechanism but only a complaints box. In some workplaces, employees were asked to make direct complaints to the managers, officers and even NGOs. Again, in a few workplaces, the committee which addresses the issues of child sexual abuse also attends the cases of SHWWP.

\section{Composition of the ICs}

The Act provides guidelines for the constitution of the IC. According to the Act, there should be a Presiding Officer, not less than two (2) members from the employee and one member from an NGO or association committed for the cause of women. Therefore, the committee should comprise of minimum 4 members. Of the existing $31 \%$ of the ICs, only $13.8 \%$ of them have number of members as laid out in the Act. On one extreme some of the complaint committees comprise of two or three members, and on the other extreme there were up to 30 members.

\section{Mode of Lodging Complaint}

The SH Act states that any aggrieved woman may make a written complaint about sexual harassment at the workplace to the Internal or Local Committee. Where such complaints cannot be made in writing, the Presiding Officer or any member of the Internal or Local Committee shall render all reasonable assistance to the woman for making the complaint in writing. Figure 4 shows that as per the findings from the employers, in the few workplaces that had ICS, approximately $31 \%$ of the complaints were lodged in written form, while 54\% complaints were made verbally and were written out by IC members and $6 \%$ were only verbal (Vauquline and Hazarika, 2019). 


\section{Low Lodging of Complaint}

One of the most alarming facts that emerged in the study was that only $2.7 \%$ of the women have lodge written complaints. On many occasion, it is observed that even after the existence of complaint mechanism, complains were not lodged. When analysed from the employees' perspectives, one of the primary factors of lower complaint is the aggrieved person not being aware of how and whom to address to in such situations. At times, the problems of the aggrieved employees are not addressed because of improper as well as inadequate complaint. However, in most cases the aggrieved women were themselves reluctant to complain for varied reasons which were diverse and complex. This observation validates the observation made by Bhattacharyya (2015; 2016; 2018).

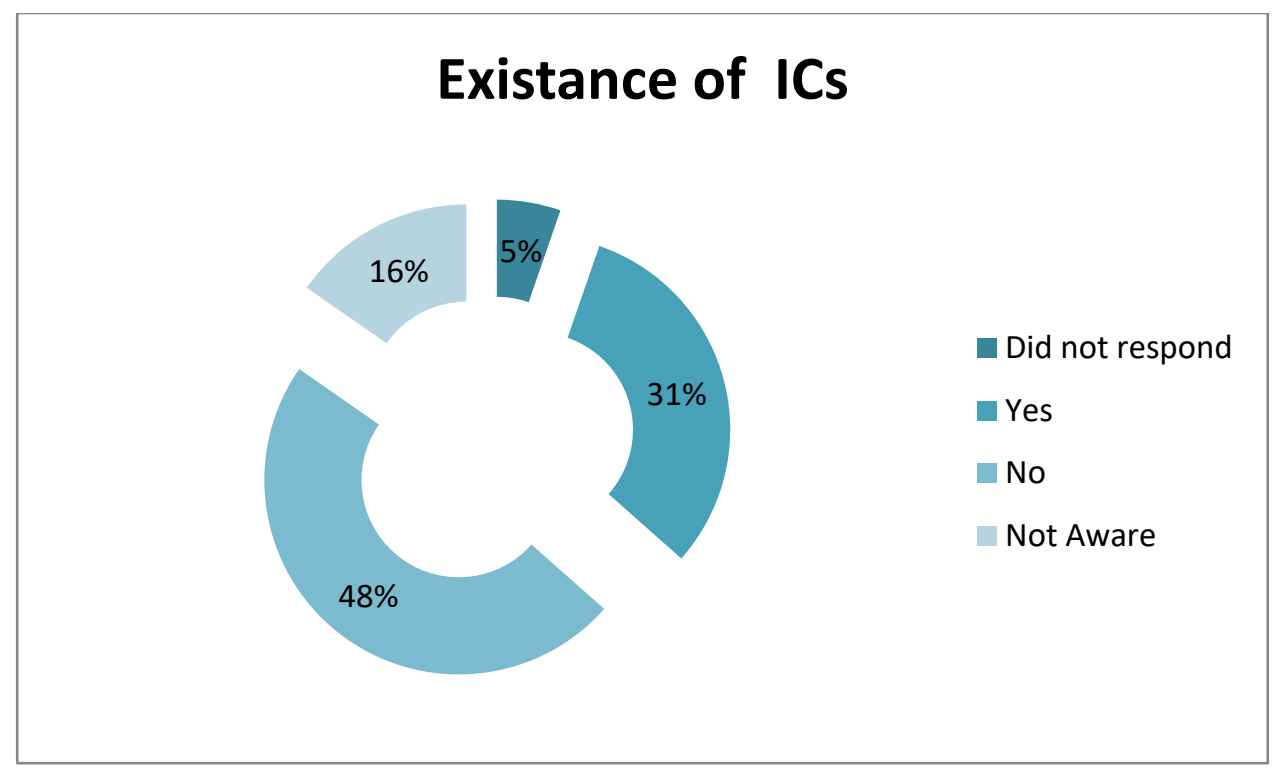

Figure 3: Existence of ICs

Source: Prevention, Prohibition and Redressal of Sexual Harassment at Professional Places in Assam: Post 23rd April, 2013

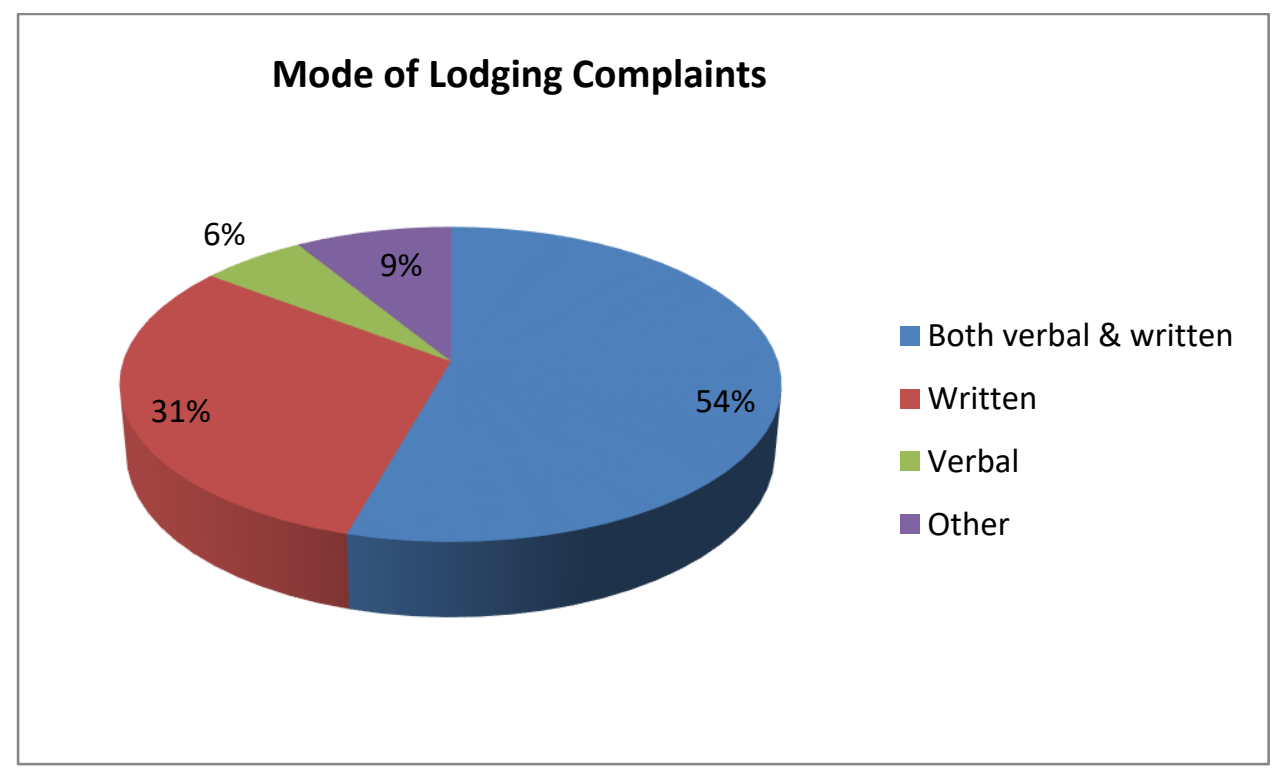

Figure 4: Mode of Lodging Complaint Source: Workplace Safety and Dignity for Women in Assam 
When investigated from the employers' perspectives it was revealed that they do not want any official record of such complaints, fearing it would stigmatise their organisation; therefore they discourage aggrieved women who are willing to report their complaints from doing so. In most of the cases, it was found that the employers', did not feel that it was necessary to establish complaint mechanism in their workplace as 'such acts' did not exist in their organisations. Thereby, no complaint mechanism and no complaint lodged.

\section{Conclusion}

The study portrayed that SHWWP is diverse and complex in nature where power relationship plays a distinctive role for which many of the incidences were silently accepted and went unreported. Again, the value of a permanent job overshadowed the occurrences of SHWWP and was considered as trivial matter in comparison to other hardships women faced otherwise in their day to day life. For the majority of the respondents, the importance of a well-paid permanent job was far more critical than $\mathrm{SH}$, and hence they fell as easy prey to sexual harassment at workplace (Bhattacharyya, 2018). Their subordinate position at large in Indian society to a great extent contributed to women normalising and internalising such situations. These also diminish their understanding of the importance of dignified workplace environment.

The above findings clearly illustrate that the Sexual Harassment of Women at Workplace (Prevention, Prohibition and Redressal) Act, 2013 is very poorly implemented in the organised workplaces in Assam. In many workplaces it is not even put into practice. As such the issue of redressal of SHWWP in Assam is in frail condition. It can also be concluded that mere existence of the Act will not address the grave issues of SHWWP. Along with it calls for rigorous awareness drive and sincere effort by the Government for the execution of the Act. There are provisions (26.1) in the Act which mentions that if an employer fails to constitute an IC s/he 'shall be punishable with fine which may extend to fifty thousand rupees'. If this provision along with the others is compelled to be put into practice there is huge possibility of establishment of IC.

The study further revealed that though the Sexual Harassment at Workplaces Act, 2013 was introduced in 2013, but the very purpose of the Act is still not been served in its true sense. It was observed during the study that the employers, employee and students were more or less aware about SH as a concept and SH Act, 2013 as an additional knowledge, but in terms of filing complaints as aggrieved women, except for a few, the majorities of them were reluctant and hesitant to lodge complaints. Another reason behind their reluctances was the long duration it undertook to resolve the cases of sexual harassment. Again, it was found out that people still blame the victims not the perpetrators for such incidents. Despite the awareness programmes organised on sexual harassment at workplaces, the mind-set of both the male and female employees as well as employers of the organisations surveyed have not changed. Some of them supported the stereotypical ideas about the behaviour of the female employees with their male colleagues. Due to lack of existence of supportive mechanism, which was not favourable for women, some of the male employees were actively indulged in such incidents.

It is the right of every employee to work in a safe and comfortable work environment with dignity. Along with redressal, when efforts and initiatives are taken by the employers for prevention and prohibition of SHWWP, the workplaces environment will subsequently become conducive for women to participate as productive and efficient member of the organisation. There should be zero tolerance to SHWWP. Even small matters/incidences should be dealt with grave sincerity. $\mathrm{SH}$ should be treated as unacceptable and intolerable act in the workplace. These proactive steps and attitudes can definitely bring in changes the workplaces of Assam.

\section{References}

Benson, D. \& Thomson, G. (1982). Sexual harassment on a university campus: The confluence of authority relations, 
sexual interest, and gender stratification. Social Problems, 29(3), 236-251.

Bhattacharyya. R. (2018). \# Metoo Movement: An Awareness Campaign. International Journal of Innovation, Creativity and Change, 3 (4), Retrieved on 30 October 2019 from, http://www.ijicc.net/images/Mrach18 _spec_edition/battacharyarra_March1 8.pdf

Bhattacharyya, R (2015). Understanding the spatialities of sexual assault against Indian women in India. Gender, Place \& Culture: A Journal of Feminist Geography, 22(9), 1340-1356, http://dx.doi.org/10.1080/0966369X.2 014.969684

Bhattacharyya, R. (2016). Street violence against women in India: Mapping prevention strategies. Asian Social Work and Policy Review, 10(3), 311325, doi: 10.1111/aswp.12099

Cela, A. (2015). Sexual Harassment at Work: A European Experience. Academic Journal of Business Administration, Law and Social Sciences, 1(1),80-91. Retrieved on 14 November 2019 from, http://iipccl.org/wpcontent/uploads/2015/03/Ajbals-8091.pdf

Chachra, M. (2017, 04 March). Despite law, 70\% working women don't report workplace sexual harassment, employers show poor compliance. The Economic Times. Retrieved on 30 August 2019 from, https://economictimes.indiatimes.com /news/company/corporatetrends/despite-law-70-workingwomen-dont-report-workplace-sexualharassment/articleshow/57464870.cm s.

Dasgupta, R. (2001). The Politics of Silence: Sexual Harassment at Workplace. Kolkata: Sanhita.
Gupta, S.S. and Hazra, A. (2007). Prevention of sexual harassment at workplace: $A$ handbook (5-26.). Calcutta: Sanhita.

Institute of Social Development. (2014). A study on protection of Women from Sexual Harassment at Workplace in different Sectors, A situational Analysis of Workplaces in Bhubaneswar City. Institute of Social Development, Bhubaneswar.

Kakoti Borah, P. (2018). Engaging with the Law: Decriminalisation of Homosexuality and the Johar Judgement, 2018. Space and Culture, India, 6(3), 5-22. https://doi.org/10.20896/saci.v6i3.400

Kihnley, J. (2000). Unravelling the Ivory Fabric: Institutional Obstacles to the Handling of Sexual Harassment Complaints, Law \& Social Inquiry, 25 (1), 69-90 (Winter). Blackwell. Retrieved on 30 March 2019 fromhttp://www.jstor.org/stable/8290 18.

McCann, D.( 2005). Conditions of Work and Employment Programme. International Labour Office.

Ministry of Women and Child Development. (2015). Handbook of Sexual Harassment of Women at Work Place, Act 2013. Delhi: Government of India, Ministry of Women and Child Development.

Morgan, P. (2001). Sexual Harassment: Violence Against Women at Work, in C. M. Renzetti, J., L. Edleson \& R. K. Bergen (Eds.), Source Book on Violence Against Women (pp: 209-220). Thousand Oaks, California: Sage Publication.

Murthy, L. (2004). Sexual Harassment at the Workplace. Women's Studies and Development Centre, Secretariat for the Interim Apex Committee on Sexual Harassment, New Delhi.

National Crimes Record Bureau. (2017). Ministry of Home Affairs. Govt. of India, N. Delhi. 
Pradeep, R. \& Ray, A. (2017). Challenges in Implementation of the Sexual Harassment of Women at Workplace. Retrieved from https://www.shrm.org/shrmindia/pages/india-challenges-inimplementation-of-the-sexualharassment-of-women-atworkplace.aspx

Raghuwanshi, A. (2017). The Critical Analysis of Sexual Harassment of Women at Workplace (Prevention, Prohibition and Redressal) Act, 2013. International Journal of Legal Insight, 1(3)

Reskin, B. \& Padavic, I. (1994). Women and Men at Work. Thousand Oaks, CA: Pine Forge

Rutter, P. (1989). Sex in the forbidden zone: When men in power-therapists, doctors, clergy, teachers, and othersbetray women's trust. New York: Fawcett.

Sarma Bhattacharyya, R. (2009). Feminist Political Economy. In R. Kitchin and N. Thrift (eds.). The International Encyclopedia of Human Geography, Oxford: Elsevier, 4, 79-86

Stambaugh, P. M. (1997). The power of law and the sexual harassment complaints of women. National Women's Studies Association Journal, 9(2) 23-42.

Vauquline, P. (2007). Gender Related Crimes in Greater Guwahati Urban Area. Ph.D. Thesis. North Eastern Hill University, Shillong.
Vauquline, P. (2012). Urbanisation and Violence against Women. Radix International Journal of Research In Social Science, 1, 1-20.

Vauquline, P. \& Hazarika, A. (2019). Workplace Safety and Dignity for Women in Assam, A Research Report, Department of Women's Studies, Gauhati University and North East Network

Vauquline, P. \& Dutta, J. (2019). Prevention, Prohibition and Redressal of Sexual Harassment at Professional Places in Assam: Post 23 ${ }^{\text {rd }}$ April, 2013, unpublished UGC Major Research Project of Department of Women's Studies, Gauhati University.

Welsh, Sandy (1999). Gender and Sexual Harassment. Annual Review of Sociology. 24, 169-190, https://doi.org/10.1146/annurev.soc.2 5.1.169

\section{Acknowledgements}

This article is based in the findings of two research projects. The first study is a collaborative research project, Workplace Safety and Dignity for Women in Assam, A Research Report with North East Network, Guwahati, Assam and the Department of Women's Studies, Gauhati University where the author, Dr. Polly Vauquline and Anurita Hazarika are the Principal Investigators. The second study is a UGC sponsored Major Research Project, Prevention, Prohibition and Redressal of Sexual Harassment at Professional Places in Assam: Post 23rd April, 2013, where the author is the Principal Investigator and Dr Jyotisikha Dutta is the CoInvestigator. 